not really in evidence until 1957 even though they quote George Gay (1911) as writing 'everyone knows it to be a wellestablished fact that a person in his right mind has a right to decide as to whether any operation shall be performed upon himself (page 83). In the face of this kind of remark an argument from silence loses some of its force. They discuss the complex issues in research ethics and the need for compromise, particularly where deception forms part of the methodology. Federal policy and the triumph of autonomy occupy a rather laboured chapter which is followed by a rich and detailed philosophical exploration of consent.

They develop a helpful analysis in terms of intentionality, understanding and control followed by three wellillustrated chapters on consent in practice.

The authors draw a careful distinction between substantially autonomous consent and (legally/ socially) effective consent and give an insightful analysis of competence to give consent as a multifactorial ability.

A substantial chapter on substantial understanding heralds the way for a weighted view of autonomous consent, sprinkled with useful suggestions about communication and its difficulties. Their final remarks place emphasis on the need for reason-giving explanation so that the patient is enabled to give intelligent authorisation for any therapy.

For the average doctor this would be a daunting tome, even though the clarity, insight and incisiveness of much of the discussion are qualities much beloved by surgeons. One could say that this 'cloud of scholarship' needs to be distilled into a 'drop' of ethical wisdom.

GRANT GILLETT Fellow in Philosophy, Magdalen College, Oxford

\section{Applied Ethics}

Peter Singer, editor, 254 pages, Oxford, $£ 15$, Oxford University Press, 1986

Suppose you have two patients, one who needs a new kidney and one who needs a new heart. Both are urgent requirements but donors cannot be found. Do you face a pressing moral dilemma? Do you think it would be a good idea to kill one of your healthy patients and thereby save two lives for the price of one? If you do, then one of the writers in this collection, John Harris, has something to tell you: there is no compelling moral theory which would indicate that you should not. In case you have any misplaced squeamishness about bumping off the unsuspecting lad who has just dropped by for his father's sick-note, Harris will spare your feelings. The donor would be chosen by lottery so that no one could complain that the procedure was unfair or arbitrary. Of course, the idea may never have crossed your mind, so perhaps we should just move on.

Did you know that since a newborn baby has no sense of self - and we all know what that means - there is no moral difference between killing it and killing a kitten. At least, not if the baby is under a week old. Michael Tooley says so. Sadly, the age of the kitten is not specified. However, it should be noted that this conclusion applies to all babies, not only to the irremediably impaired or suffering. It is a somewhat Draconian remedy for over-population.

James Rachels is a little more realistic. His problem concerns the terminally-ill patient in acute pain. Rachels knows you must comply with the law, but, really doctor, only your muddled upbringing could lead you to think that there is any relevant moral distinction between killing and letting die.

These articles on medical ethics, like most in the collection, were written in the early 1970s or before. It shows. Mercifully, the thinking on such topics has matured since then. It is beginning to be understood that to do applied ethics it is necessary for philosophers to see themselves as participants in the moral dramas and not as mere observers. Participants do not start with an abstract problem but with one which arises in an existing network of relationships which themselves have moral significance. It is no longer considered acceptable to conduct discussions about killing and letting die or about abortion and infanticide without recognising that these involve agents, people who may or may not do these things. The question is not whether there is a moral difference between killing and letting die, but whether there is a difference between you killing me and you letting me die. Harris's, Rachels's and Tooley's enquirers, whoever else they may be, are clearly not doctors. There is no acknowledgement in these writings that at the heart of the cases lies a doctor/ patient relationship which would make survival lotteries a nonsense and the extermination of babies a non-starter.

Only Judith Jarvis Thomson, in her already well-known article on abortion, shows any sensitivity on this point. She tells us that who you are makes a difference to what you may do, a simple but crucial thought. We know it to be true in many areas of our lives. There are things I may not say to my children because I am their mother; things you may not say to them because you are not. If you are my doctor then you cannot also be my executioner; if you are to assist me to commit euthanasia then it is not just linguistic nicety which requires that we discover whether we can distinguish this kind of killing from others and that we do so in the context of a relationship which is founded on trust. There seems little point in republishing articles such as these, which are so out-dated and which have been so thoroughly discussed, unless it is to provide a stern reminder to students of how not to tackle the serious problems in medical ethics.

JUDITH HUGHES University of Newcastle upon Tyne

\section{On Moral Medicine: Theological Perspectives in Medical Ethics}

Stephen E Lammers and Allen Verhey, editors, 667 pages, Michigan USA, $\$ 24.95$, William B Eerdmans Publishing Co, 1987.

Between conception and death moral questions crop up. Some - about conception and death themselves, for instance - touch on medical practice. Such questions may be discussed with or without reference to God. This book favours the former approach. That raises further questions. The sub-title is a little too broad, since not all theology is Christian. While there is some reference in this reader to Jewish traditions (for example, in Gradwohl's piece on $A$ fewish Approach to the Issue of 'Experiments with Man'), one looks in vain for signs of other traditions from the same continent, such as Islamic or Hindu.

The perspective of these reprinted pieces is, then, predominantly Christian. Within that, they appear to be mainly Protestant. While Roman Catholic teaching is represented, it hardly dominates the collection and the juxtaposition of articles may be significant. Humanae Vitae, Pope Paul VI's encyclical on human life, with what some will think its brutally clear proscription of 'the direct interruption 
of the generative process already begun and, above all, directly willed and procured abortion, even if for therapeutic reasons', is followed at once by a dissenting piece by Charles Curran which sets out some main objections to the Pope's position.

Some secular articles are included too, but mainly to challenge the faithful. As the preface makes clear, the first criterion for selection is, not surprisingly, that each article should articulate a theological perspective or at least be of theological interest.

Indeed, as the editors explain, the 105 articles and excerpts in this collection have been selected and reprinted primarily for courses in religious studies departments, and 'institutions which preserve and nurture a lively sense of the Christian tradition'. The collection reflects the editors' dissatisfaction with a merely secular medical morality based on impartial rational principles, whether these be respect for individuals' autonomy, or utilitarianism (estimating actions' consequences in terms of human happiness).

How would the editors replace or complement such secular morality? Characteristically, the articles appeal less to formal moral arguments than to faith in Christian principles such as the sacredness of human life, or, as Karl Barth puts it, writing on the protection of life, 'a feeling of awe at the mystery of all human life as this is commanded by God its creator'. (For the Protestant Barth, this awe precludes abortion, except in very exceptional cases.)

Such theological perspectives may come into conflict with secular moral principles of autonomy or happiness.

Moreover, a number of the authors attack secular erosion of the scope of moral responsibility. For example, in a clearly written article opposing the sweeping World Health Organisation definition of health, Daniel Callahan complains that this definition propels all social ills, such as poverty, into the realm of ill-health. This would absolve us from moral responsibility for those ills. Callahan over-compensates: his own definition of health as 'a state of physical well-being' appears to imply that there can be no such thing as mental illness.

The Protestant moral traditions at the heart of this book are traditions. Secularist readers may lose patience but they might reflect that no livec morality is completely divorced from tradition, and that no morality, as David Hume saw, can get by without drawing on something in addition ton reason. Whether we choose to be guided" by fellow-feeling, by principles of $\overrightarrow{0}$ autonomy or utility, by God, or by some combination of these, medical ethics $\vec{\omega}$ will continue to throw up painful dilemmas. Technological and social change will add to these, and makethem more acute. This book brings. $\omega$ change and one tradition face to face.

The editors' linking introductions are N clearly written, and the articles? themselves range in style from lucido (such as Verhey's own) to slightly selfimportant (such as Paul Ramsey's).

DONALD HILL Polytechnic of North London, 